\title{
Thermochemical energy storage by consecutive reactions for higher efficient concentrated solar power plants (CSP): proof of concept
}

\author{
Luisa F. Cabeza ${ }^{1 *}$, Aran Solé ${ }^{1}$, Xavier Fontanet ${ }^{1}$, Camila Barreneche ${ }^{1,2}$, Aleix Jové, \\ Manuel Gallas ${ }^{3}$, Cristina Prieto ${ }^{3}$, A. Inés Fernández ${ }^{2}$ \\ ${ }^{1}$ GREA Innovació Concurrent, Universitat de Lleida, Lleida, Spain. Edifici CREA, Pere de Cabrera s/n, 25001 Lleida, Spain. \\ ${ }^{2}$ DIOPMA Department of Materials Science \& Metallurgical Engineering, Universitat de Barcelona, Barcelona, Spain. Martí i \\ Franqués 1-11, 08028 Barcelona, Spain \\ ${ }^{3}$ Abengoa Research, C/Energía Solar 1, 41012 Seville, Spain \\ *Corresponding author e-mail: lcabeza@diei.udl.cat
}

\begin{abstract}
Concentrated solar power plants (CSP) combined with thermal energy storage (TES) offers the benefit to provide continuous electricity production by renewable energy feed. There are several TES technologies to be implemented, being the thermochemical energy storage the less studied and the most attractive since its volumetric energy density is 5 and 10 times higher than latent and sensible TES, respectively. Thermochemical energy storage technology is based on reversible chemical reactions, also named thermochemical materials (TCM). One of the main challenges of TCM is to achieve a proper reversibility of the reactions, which in practical conditions leads to lower efficiencies than the theoretically expected. A new concept based on changing from reversible TCM reactions towards TCM consecutive reactions aims to eliminate reversibility problems and therefore improve the overall efficiency. Consecutive TCM reactions can either be based in one cycle, where reactants are needed to feed the reaction, or two coupled cycles which offer the possibility to work without any extra mass reactants input. The plausibility of the implementation of both concepts in CSP is detailed in this paper and case studies are described for each one.
\end{abstract}

Keywords: Thermal Energy Storage (TES); Thermochemical materials (TCM); High temperature; Concentrated Solar Power plant (CSP); Consecutive reactions

\section{Introduction}

The fact of taking profit from renewable energies, like solar energy, and turning to sustainable and competitive energy systems is in agreement with the current world wide directives and H2020 [1]. The general target is focused on reducing fossil fuel consumption for electricity production, heating, and cooling in order to decrease $\mathrm{CO}_{2}$ emissions and thus support climate change goals. Regarding electricity production, concentrated solar power (CSP) plants are attractive alternative technologies. CSP technologies generate electricity by concentrating the solar radiation beam onto a small area, where a heat transfer fluid (HTF) is heated up and this 
energy is ultimately transferred to the steam. Electricity is then generated by an electric generator which is driven by a steam turbine with the efficiency limited by the Carnot cycle [2].

Today, several countries such as USA or Spain have developed commercial CSP plants $[3,4]$ which are using different technologies to concentrate the solar beam. Nowadays, four CSP technologies are represented at pilot and commercial scale: parabolic-trough collectors (PTCs), linear Fresnel reflector (LFR) systems, power towers or central receiver systems (CRS), and dish/engine systems (DE). All existing plants imitate parabolic geometries with large surface area for the mirrors [4].

Energy production is restricted when sun shines, therefore, a system that allows storing solar heat is required. In case of not having problems with sun shine, a producer company might want to store the energy as a function of the price of $\mathrm{kWh}$ on the market (to increase company benefits). For this purpose a thermal energy storage system (TES) is essential. TES is becoming particularly important for electricity storage in combination with concentrating solar power (CSP) plants where solar heat can be stored for electricity production when sunlight is not available $[5,6]$.

Proposed mechanisms to store thermal energy are based on different physical or chemical principles: sensible heat (molten salts, solid particle materials, etc.), latent heat by means of phase change materials (PCM), and thermochemical heat storage (TCS) using thermochemical materials (TCM) [7-13]. Nowadays, the use of molten salts is the most viable alternative for TES coming from solar heat to supply intermittent power demand. Nevertheless, molten salts cannot provide a temperature or an energy density as high as the TCS due to the mechanism itself. From a theoretical point of view the use TCS is a challenge that can provide higher storage of energy for longer periods and operate at higher temperatures compared to the other mentioned systems. Consequently, implementing TCS technology would allow increase efficiency of a CSP plant $[5,6]$. This topic has experienced a remarkable increased perception in the last few years and thus several studies are being published. For instance, modeling of redox reactions where the model is shown to track complex trends in measured non-stoichiometry data, specific heat capacity, and global heats of reaction with respect to changes in $\mathrm{T}$ and $\mathrm{p}_{\mathrm{O} 2}$ [14], novel concepts based coupling a CSP-CaL process and $\mathrm{CO}_{2}$ power cycle [15], cascade thermochemical storage with internal condensation [16], algorithm for searching potential thermochemical energy storage for a wide temperature range $\left(25-1000^{\circ} \mathrm{C}\right)[17]$, etc.

Actually, TCS for CSP is based on reversible reactions with high enthalpy of reaction but these reactions presented low efficiency and poor reversibility. The trend is to use heterogeneous 


\section{2}

reactions (solid-gas) to facilitate the removal and transport of the gases involved in the reaction. Redox systems based on oxide pairs, i.e. $\mathrm{Mn}_{3} \mathrm{O}_{4} / \mathrm{Mn}_{2} \mathrm{O}_{3}[12,13]$ are the most used to achieve the requirements and maintain material stability. The storage mechanism can be defined as depicted in equation 1 :

$$
\mathrm{A}_{(\mathrm{s})} \underset{\begin{array}{c}
\text { heat release } \\
\text { exothermic reaction }
\end{array}}{\stackrel{\substack{\text { heat storage } \\
\text { endothermic reaction }}}{\longleftarrow}} \mathrm{B}_{(\mathrm{s})}+C_{(\mathrm{g})}
$$

During the charging process (endothermic reaction), solar thermal energy is used to move the reaction from the solid reactant $(\mathrm{A})$ (sometimes together with a gas reactant) to products $\mathrm{B}$ ( solid) and C (gas). During this step, the TCM is absorbing the heat concentrated at the solar receiver. The storage process consists on keeping $\mathrm{B}$ and $\mathrm{C}$ products separated. In order to discharge the system (exothermic reaction), the former solid product, $\mathrm{B}$, is placed in contact with the gas $\mathrm{C}$, to react and thus release the chemical reactions energy between the product stored.

The problem that is seen from the TCS systems prototypes is that the reaction must be reversible and this premise is not being fully achieved. This implies that the chemical conversion and reversibility of the reaction $[18,19]$ is not fulfilled and therefore the storage capacity differs from the expected. This makes difficult to find a TCM that can be adjusted to the theoretical model and in all, it will be difficult to implement TCS systems with the established premises.

The main objective of this paper is to demonstrate the feasibility of a new concept of a CSP plant with solar central receiver reactors technology implementing thermochemical materials. This concept overcomes the drawback of the poor reversibility and low efficiencies in high temperature storage by changing from the reversible reactions towards TCM consecutive reactions. To illustrate this, two case studies are shown, one for a one cycle of TCM consecutive reactions and another for two coupled cycles of TCM consecutive reactions.

\section{Consecutive TCM reactions}

Two different concepts, one based on one cycle and the other based on two coupled cycles of consecutive TCM reaction were developed $[20,21]$ and are presented in this section. 


\subsection{One cycle TCM consecutive reaction, a case study $\mathrm{Zn}+\mathrm{CO}_{2}$}

\subsubsection{Presentation of the concept}

114

The general concept of one cycle of TCM consecutive reactions is depicted in Figure 1. The initial solid A is transformed into another solid B and a gas C, this last solid reacts with another gas $\mathrm{D}$, giving the initial solid $\mathrm{A}$ and a gas $\mathrm{E}$. The consecutive reaction can be running being the only input the gas $\mathrm{D}$ in the second reaction.

Figure 1. Simplified scheme of the consecutive reactions concept: one cycle.

As an example of this concept, the $\mathrm{ZnO} / \mathrm{Zn}$ cycle is considered. The first step is the endothermic thermal reduction $\left(\Delta \mathrm{H}_{298 \mathrm{~K}}=350.85 \mathrm{~kJ} \cdot \mathrm{mol}^{-1}\right)$ of zinc oxide and can be referred as the solar step $\left.\mathrm{kJ} \cdot \mathrm{mol}^{-1}\right)$ of $\mathrm{CO}_{2}$ with zinc to generate $\mathrm{CO}$ and $\mathrm{ZnO}[22,23]$.

$$
\begin{gathered}
\mathrm{ZnO}_{(s)} \rightarrow \mathrm{Zn}_{(g)}+\frac{1}{2} \mathrm{O}_{2(g)} \\
\mathrm{Zn}_{(g)}+\mathrm{CO}_{2(g)} \rightarrow \mathrm{ZnO}_{(s)}+\mathrm{CO}_{(g)}
\end{gathered}
$$

The thermal reduction of $\mathrm{ZnO}$ can be performed at $1627-1727^{\circ} \mathrm{C}[24,25]$ at 1 bar and inert atmosphere $\left(\mathrm{N}_{2}\right.$ or Ar). After this thermal reduction, zinc is obtained in gas form $\left(\mathrm{T}_{\mathrm{b}}=912^{\circ} \mathrm{C}\right)$

133 [26]. Afterwards, in the non-solar step, the produced $\mathrm{Zn}$ gas reacts with $\mathrm{CO}_{2}$ giving the initial oxide (solid) and CO. This second reaction may be performed at temperatures below $\mathrm{ZnO}$ thermal decomposition. However, it presents a high resistance due to the formation of an oxide layer which slows the reaction (Figure 2) which drops the chemical conversion [23]. This phenomenon can determine the working temperature, because at temperatures lower than $912^{\circ} \mathrm{C}$ 
that perform $\mathrm{CO}_{2}$ splitting using liquid $\mathrm{Zn}$ achieved less than $50 \%$ of $\mathrm{Zn}$ conversion at $500^{\circ} \mathrm{C}$

$143[22,23,27,28]$. Having a phase change can facilitate the reduction of the thermal reduction 144 temperature through decreasing the system pressure.

143

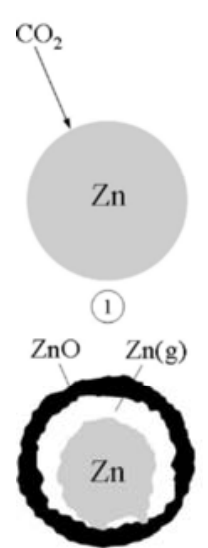

(3)

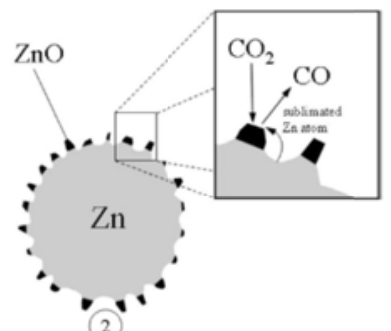

Figure 2. Scheme of $\mathrm{CO}_{2}$ splitting mechanism [23].

Table 1 shows the enthalpy of each reaction of the thermochemical heat storage system. The optimal working temperature $\left(\mathrm{T}_{\mathrm{w}}\right)$ and the maximum chemical efficiency $(\mathrm{X})$ calculated in bibliography or estimated have been taken into account. Therefore, three values of enthalpy are shown at $25^{\circ} \mathrm{C}$, at optimum Tw and, at optimum Tw taking into account the maximum chemical efficiency.

Table 1. Enthalpy of reaction at different conditions (1 atm), working temperature (Tw), and maximum chemical efficiency $(X)$.

\begin{tabular}{|c|c|c|c|c|c|}
\hline Reaction & $\operatorname{Tw}\left({ }^{\circ} \mathbf{C}\right)$ & $\mathrm{X}(\%)$ & $\begin{array}{l}\Delta \mathrm{H}_{298 \mathrm{~K}} \\
(\mathrm{~kJ} / \mathrm{kg})\end{array}$ & $\begin{array}{c}\Delta \mathrm{H}_{\mathbb{T}} \\
(\mathrm{kJ} / \mathrm{kg})\end{array}$ & $\begin{array}{r}\Delta \mathrm{H}_{\mathrm{T}, \mathrm{X}} \\
(\mathrm{kJ} / \mathrm{kg})\end{array}$ \\
\hline$Z n O_{(s)} \rightarrow Z n_{(g)}+\frac{1}{2} O_{2(g)}$ & 1700 & 95 & 2072 & 2631 & 2769 \\
\hline $\mathrm{Zn}_{(g)}+\mathrm{CO}_{2(g)} \rightarrow \mathrm{ZnO}_{(s)}+\mathrm{Co}_{(g)}$ & 1000 & 95 & -400 & -272 & -258 \\
\hline
\end{tabular}

\subsubsection{Engineering diagram and plant application}

Figure 3 shows a possible engineering scheme of the $\mathrm{ZnO} / \mathrm{Zn}$ system implemented in a CSP plant. Therefore the proposed configuration is to perform Eq. 2 in a direct (closed) rotary kiln $[29,30]$, and then to separate the $\mathrm{Zn}$ from the $\mathrm{O}_{2}$ in a condenser (at $\mathrm{T}$ below $912^{\circ} \mathrm{C}$ ) and finally reaction following Eq. 3 is performed in an indirect or non-solar fluidized bed reactor. The main drawback of this system is the phase change of $\mathrm{Zn}$, which determines the phase that the $\mathrm{Zn}$ will be during the $\mathrm{CO}_{2}$ splitting. 


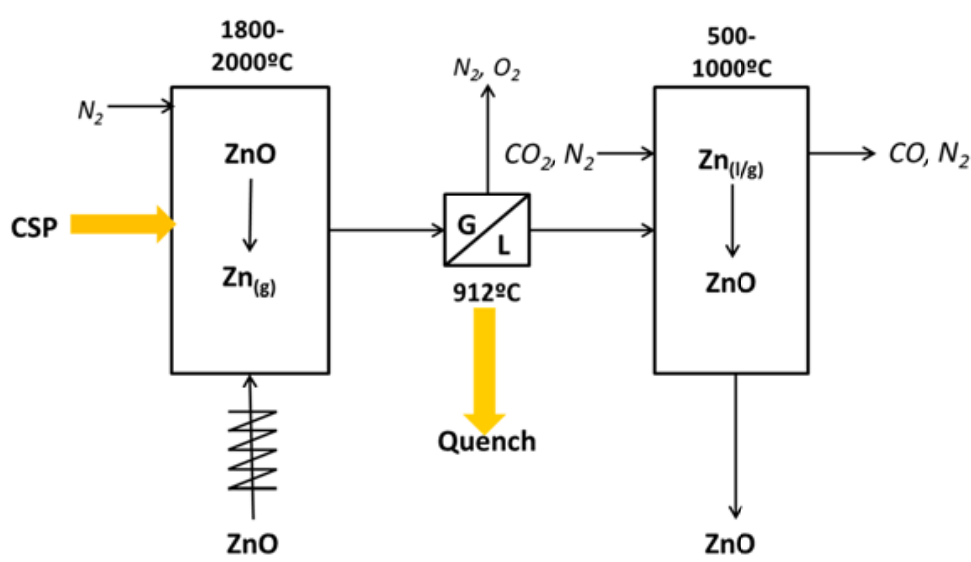

Figure 3. Scheme of the single cycle based in $\mathrm{ZnO} / \mathrm{Zn}$ consecutive reactions.

An interesting point is to use the heat generated in the condenser to preheat the $\mathrm{Zn}$ before entering the fluidized bed. The reaction kinetics will be higher, but the most important point is to prevent the oxide layer formation. With this concept it can be considered a cycle of consecutive reactions with three steps, where it is not necessary to store $\mathrm{Zn}$. Another aspect to take into account is that reaction shown in the Eq. 3 is exothermic, and thus preheating of $\mathrm{CO}_{2} / \mathrm{CO} / \mathrm{N}_{2}$ mixture (rich in $\mathrm{CO}_{2}$ ) may not be required. Therefore, this is why a reactor without receiver is proposed.

Advantages of this specific one cycle of consecutive TCM reactions is the low cost of $\mathrm{ZnO}$, well know thermal decomposition of $\mathrm{ZnO}$ in a solar receiver/reactor, only needs one receiver, can operate at 1 bar, easy to separate gases, it allows heat storage and also $\mathrm{CO}_{2}$ capture. On the contrary, as disadvantages there are the phase change of $\mathrm{Zn}$, maintenance can be complicated by $\mathrm{Zn}$ condensation, requires temperatures higher than $1000{ }^{\circ} \mathrm{C}$, presumed low absorptivity (white material), thermodynamic constraints (low solar-to-chemical efficiency for solar step, higher than other cycles, i.e. $\mathrm{Fe}_{3} \mathrm{O}_{4} / \mathrm{FeO}$ ), and $\mathrm{CO}$ generation.

It is important to highlight that $\mathrm{CO} / \mathrm{CO}_{2}$ is released/consumed because the example is based on a specific reactions being a case study to show the concept, but other reactions with other pair of gases can be found for each application. 

$\mathrm{Mn}_{3} \mathrm{O}_{4} / \mathrm{Mn}_{2} \mathrm{O}_{3}$

\subsubsection{General concept}

196

197

Since the main drawback of the one cycle TCM consecutive reactions is the need of a reactant input, a new concept is presented where this reactant is produced in a second coupled cycle to close completely the system by generating and regenerating within the reaction all the products and reactants. The general concept of two coupled cycles TCM consecutive reactions is drawn in Figure 4.

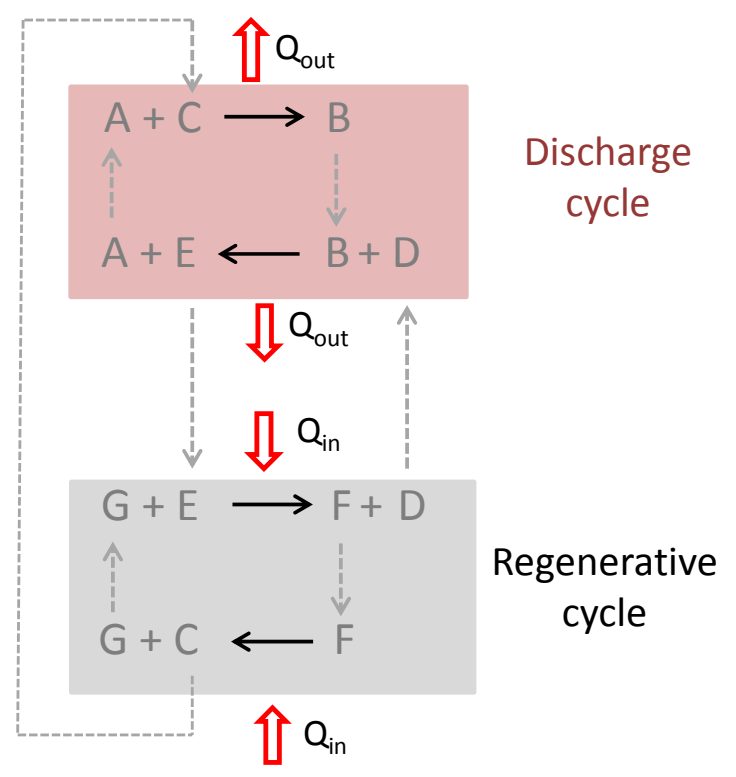

This approach of storing the TCM and not the solar heat, can be very similar to those proposed for obtaining solar fuels, fuel for fuel cells or via water or $\mathrm{CO}_{2}$ splitting (WS and CS, respectively) [27, 42-48]. However, the difference is that the material is used for WS and/or CS to produce a chemical to store $\left(\mathrm{H}_{2}, \mathrm{CO}_{2}\right)$, and further perform another process such as FischerTropsch which allows benefiting solar heat. Instead, in the proposed system, the material is directly stored with the function of storing heat.

In conclusion, a TCS system based in four consecutive reactions divided in two-loops. One of them is exothermic and the other is endothermic, so it can be considered the discharge cycle as the discharge process and the regenerative cycle as the charge cycle; in energy terms. 
It consists in a discharging cycle and a regenerative cycle. The concept is divided into a main cycle (discharge cycle) which is focused to release heat. The other cycle (regenerative) is focused to close the system. Consequently total enthalpy of the system should be zero, and if discharge cycle is exothermic, regenerative cycle must be endothermic. In this particular concept the involved gases are $\mathrm{O}_{2}$ and $\mathrm{CO} / \mathrm{CO}_{2}$. This system of gases and the reactions involved are interesting to check in deep, in particular the thermodynamic data, conditions of work $(\mathrm{P}, \mathrm{T})$ used in many industrial processes. An example of a thermochemical storage concept based on two coupled cycles of consecutive reactions is $\mathrm{BaS} / \mathrm{BaSO}_{4}$ coupled to $\mathrm{Mn}_{3} \mathrm{O}_{4} / \mathrm{Mn}_{2} \mathrm{O}_{3}$ and shown in Eq 4- Eq 7 and drawn in Figure 5.

\section{Discharge cycle}

$$
\begin{array}{lrr}
\mathrm{BaS}_{(s)}+2 \mathrm{O}_{2(\mathrm{~g})} \rightarrow \mathrm{BaSO}_{4(s)} & \Delta H^{\circ}{ }_{850{ }^{\circ} \mathrm{C}}=-5747 \mathrm{~kJ} / \mathrm{kg} \mathrm{BaS} & \text { Eq. } 4 \\
\mathrm{BaSO}_{4(s)}+4 \mathrm{CO}_{(g)} \rightarrow \mathrm{BaS}_{(s)}+4 \mathrm{CO}_{2(g)} & \Delta{H^{\circ}}_{850{ }^{\circ} \mathrm{C}}=-933 \mathrm{~kJ} / \mathrm{kg} \mathrm{BaS} & \text { Eq. } 5
\end{array}
$$

\section{Regenerative cycle}

$$
\begin{array}{lrl}
2 \mathrm{Mn}_{3} \mathrm{O}_{4(s)}+\mathrm{CO}_{2(g)} \rightarrow 3 \mathrm{Mn}_{2} \mathrm{O}_{3(s)}+\mathrm{CO}_{(g)} & \Delta H^{\circ}{ }_{910}{ }^{\circ} \mathrm{C}=2178 \mathrm{~kJ} / \mathrm{kg} \mathrm{Mn} n_{2} \mathrm{O}_{3} & \text { Eq. } 6 \\
3 \mathrm{Mn}_{2} \mathrm{O}_{3(s)} \rightarrow 3 \mathrm{Mn}_{3} \mathrm{O}_{4(s)}+\frac{1}{2} \mathrm{O}_{2(g)} & \Delta H^{\circ}{ }_{910}{ }^{\circ} \mathrm{C}=397 \mathrm{~kJ} / \mathrm{kg} \mathrm{Mn} \mathrm{O}_{2} \mathrm{O}_{3} & \text { Eq. } 7
\end{array}
$$

As it can be seen, the system consists in four intertwined reactions, but, based on the first reaction (Eq. 4) [31-35]. A second charge reaction (Eq. 5) is necessary to recover BaS, obtaining a closed cycle for TCM. However, to perform the discharge cycle and to maintain the TCS system closed, a second cycle (regenerative cycle) is needed to regenerate/recover the product gases involved in the reactions. A third reaction (Eq. 6) regenerates $\mathrm{CO}_{2}$ produced in the second reaction, and at the same time, produces $\mathrm{CO}$ for $\mathrm{BaSO}_{4}$ reduction. The last reaction (Eq. 7) serves to close the regenerative cycle for the part of the solid, and at the same time to release $\mathrm{O}_{2}$ that is needed in the $\mathrm{BaS}$ oxidation (Eq. 5).

Unlike the TCM system concept [36-38, 39-41], in which the system store solar heat is considered, in this novel concept, solar heat is used to achieve the required temperature and the thermal energy for the desired TCM reaction. Therefore, the proposed system store chemical compounds capable to release thermal energy. 
Another difference with conventional TCM systems is that there is not a pure charge reaction.

252 Equation 4, where $\mathrm{BaSO}_{4}$ is reduced, could be considered as charging step, but is an exothermic

253

254

255

256

252 reaction, and at the same time is the reaction for recovery the BaS. On the other hand, there are two endothermic reactions (Eq. 6 and 7), but these are not directly involved on the discharge reaction. Therefore, the system is divided into a main cycle (discharge cycle) which releases heat and the other cycle (regenerative) closes the system (see Figure 5).

\section{Storage (Chemical)}

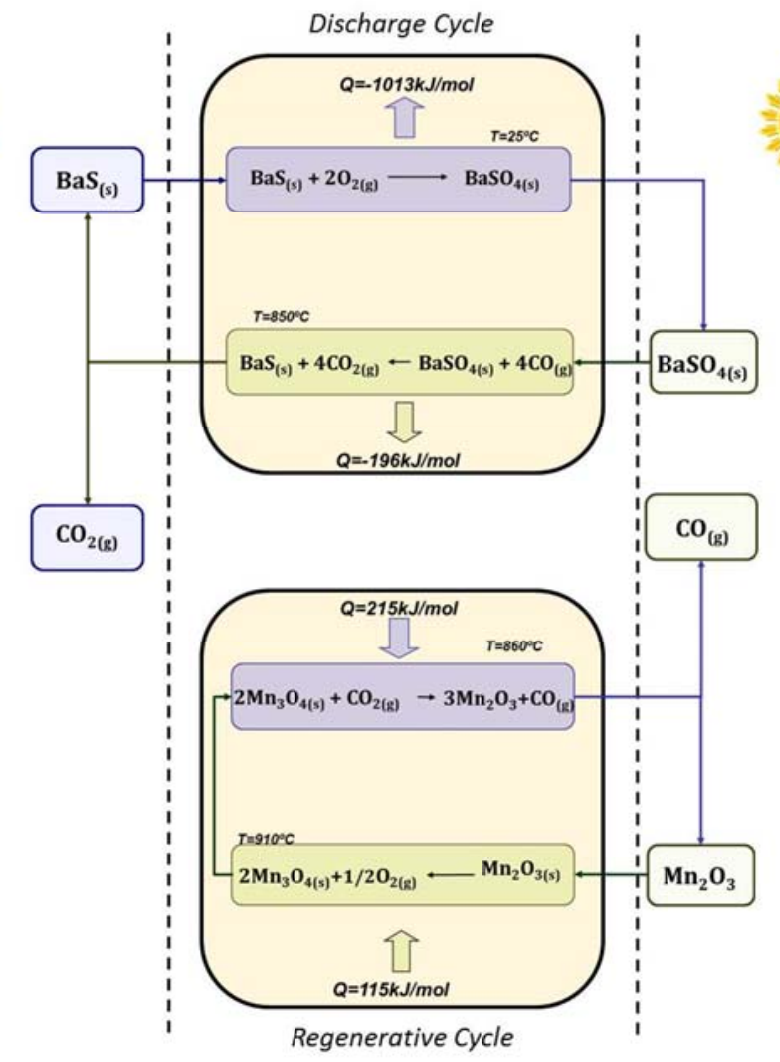

Storage (Thermal)

\footnotetext{
Figure 5. Scheme of the novel two coupled cycles of TCM consecutive reactions based on BaS oxidation.
}

\section{a. Discharge cycle}

The material used in the discharge cycle is the Barite (mineral of $\mathrm{BaSO}_{4}$ ) which can be reduced with $\mathrm{CO}$ at temperatures between $800-1000^{\circ} \mathrm{C}$ to obtain $\mathrm{BaS}[31,49-58]$. Furthermore, $\mathrm{BaS}$ can be oxidized by $\mathrm{O}_{2}$ (or air) at temperatures above $25-1400{ }^{\circ} \mathrm{C}$ [26,31- 35]. Both reactions (Eq. 4 and 5) are exothermic, and $\mathrm{BaSO}_{4}$ and $\mathrm{BaS}$ are also stable at temperatures higher than $1400{ }^{\circ} \mathrm{C}$, with melting point of $1580{ }^{\circ} \circ \mathrm{C}$ and $2229{ }^{\circ} \mathrm{C}$, respectively [26, 59]. For this reason, a discharge cycle based on $\mathrm{BaS} / \mathrm{BaSO}_{4}$ is a good candidate for a TCS system in a CSP plant.

Since barite is the industrial precursor of $\mathrm{BaS}[51,56]$ there are not many studies of $\mathrm{BaS}$ industrial combustion. However, the literature reveals that the $\mathrm{BaS}$ oxidation reaction is highly 


$$
\mathrm{BaSO}_{4(s)}+2 \mathrm{C} \rightarrow \mathrm{BaS}_{(s)}+2 \mathrm{CO}_{2(g)}
$$

For barite reduction there is literature available regarding the process on an industrial scale, however it is presented as a carbothermic reaction [51,53-56] (Eq. 8):

274

exothermic $\left(\Delta_{\mathrm{r}} \mathrm{H}^{0}=-1013.20 \mathrm{~kJ} / \mathrm{mol},-5963.75 \mathrm{~kJ} / \mathrm{kg}_{\mathrm{BaS}}\right)$ [26,31-33]. Furthermore, it is well known that sulphur $\left(\mathrm{S}^{2-}\right)$ oxidation has high reaction kinetics, and even become spontaneous [60-62]. This, added to the working temperature (800-1000 $\left.{ }^{\circ} \mathrm{C}\right)$ in a CSP plant suggests that oxidation of BaS will be a fast reaction.

Nevertheless, at temperatures higher than $800{ }^{\circ} \mathrm{C}$ carbothermal reduction is similar to equation 5 [50], because the $\mathrm{CO}$ reduction mechanism is stabilized due to the Boudouard reaction equilibrium at working temperatures [52][63]. In this manner, it works in solid-gas reactions that is easier to operate and, at the same time, $\mathrm{CO}$ is easier than $\mathrm{C}$ to recover in a regenerative cycle.

Another advantage of the $\mathrm{BaS} / \mathrm{BaSO}_{4}$ consecutive reactions in front other possible cycles as $\mathrm{MS} / \mathrm{MSO}_{4}$ (where $\mathrm{M}$ is a metal) is that $\mathrm{BaSO}_{4}$ is one of the most thermal and water stable $[26,31,60,64]$. Thermal stability of $\mathrm{BaSO}_{4}$ is only exceeded by alkali sulfates, but on the other hand, alkali sulphides have very low water stability. Sulphides of some transition metals such as $\mathrm{Fe}$, are more stable in water than $\mathrm{BaS}[26,65]$, but their sulfates have poor thermal stability. Besides the high thermal stability and relatively high stability in water of the $\mathrm{BaS} / \mathrm{BaSO}_{4}$ redox pair suggests stability in the presence of $\mathrm{CO}_{2}$ gas [51]. This means that the carbonation of the barium salt could be minimized during the $\mathrm{BaSO}_{4}$ reduction (Eq. 5) unlike what might happen with other metal sulfates. For that reason, the most attractive $\mathrm{MS} / \mathrm{MSO}_{4}$ redox pair for discharge cycle is $\mathrm{BaS} / \mathrm{BaSO}_{4}$.

Furthermore, there are some studies that evaluate the cyclability using carbothermal reduction of $\mathrm{BaS}$ [51]. Another indication which suggests the feasibility/viability of these reactions is the high melting temperature of $\mathrm{BaSO}_{4}$ and $\mathrm{BaS}$ in comparison with the working temperature, which hinders particle sintering. On the other hand, minimization of coarsing will depend, in part, on the particle size distribution and the particle shape $[66,67]$.

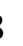


As $\mathrm{CO} / \mathrm{CO}_{2}$ is used as a reducer/oxidizer gas, the aim of the regenerative cycle is to recover $\mathrm{CO}$ from the produced $\mathrm{CO}_{2}$ in equation 5 to be reused as a reactive in the discharge cycle. Therefore, the regenerative cycle is an important part of the proposed TCS system. Due to the nature of the cycle, which reactions are endothermic, those reactions should be performed in a solar reactor/receiver located in the central tower. Paradoxically, the regenerative cycle requires solar thermal energy but not for storing thermal energy. Absorbed heat in the solar reactor/receiver is not stored as heat; rather it will serve to store CO.

$\mathrm{CO}_{2}$ is a very stable gas, so it is not usually considered an oxidizing gas although at elevated temperatures can be reduced and oxidize a reduced metal (or reduced metal oxide). The reaction mechanism is used to WS and CS, where a reduced metal is used as a reaction support (not as catalyst). Usually the used support is a cheaper reduced metal oxide such as iron oxide $\left(\mathrm{FeO} / \mathrm{Fe}_{3} \mathrm{O}_{4}\right) \quad[22,23,28,43,68,69]$; ceria oxides (CeO) $[68,70]$; or metals such as $\mathrm{Zn}$ $[22,23,43,68,71] ;$ Sn [46,47,71].

Equations 9 and 10 show the CS mechanism based on the thermal stability of the metal oxide. At a given temperature it favours the reduced or oxidized form. The reduced form always will be more thermally stable, so the reduction reactions will always be at higher temperature than the oxidation reaction. Every metal oxide redox pair has a specific temperature for thermal reduction; consequently, it could control the process by temperature control. On the other hand, the reduction reaction always requires thermal energy (endothermic reaction), but in the case of the metal oxidation (CS) reaction could be exothermic or endothermic, depending of material enthalpy formation:

325

Reduction at $\mathrm{T}_{\text {high }}$

$$
M O \stackrel{+\Delta h, T_{h i g h}}{\longleftrightarrow} M O_{1-\delta}+\frac{\delta}{2} O_{2(g)}
$$

Oxidation at $\mathrm{T}_{\text {low }}$

$$
M O_{1-\delta}+\delta C O_{2} \stackrel{ \pm \Delta h, T_{\text {low }}}{\longleftrightarrow} M O+\delta C O_{(g)}
$$

Due to the disproportionation temperature or because it may experiment a phase change in the temperature range, initially, none of the mentioned metal oxides is suitable for the system. Therefore the best options could be other redox pairs like $\mathrm{Mn}_{2} \mathrm{O}_{3} / \mathrm{Mn}_{3} \mathrm{O}_{4}$ and $\mathrm{Co}_{3} \mathrm{O}_{4} / \mathrm{CoO}$ which disproportionation temperature is in the range of the working temperature and have no phase change (Eq. 11 and 12) [40,41, 72-76]: 


$$
\begin{gathered}
3 \mathrm{Mn}_{2} \mathrm{O}_{3(s)} \stackrel{950^{\circ} \mathrm{C}}{\longrightarrow} 3 \mathrm{Mn}_{3} \mathrm{O}_{4(s)}+\frac{1}{2} \mathrm{O}_{2(g)} \\
\mathrm{Co}_{3} \mathrm{O}_{4(s)} \stackrel{913^{\circ} \mathrm{C}}{\longrightarrow} 3 \mathrm{CoO}_{(s)}+\frac{1}{2} \mathrm{O}_{2(g)}
\end{gathered}
$$

333

334

335

336

337

According to the Ellingam-Richarson diagram [32,77], $\mathrm{Mn}_{3} \mathrm{O}_{4}$ or $\mathrm{CoO}$ can reduce $\mathrm{CO}_{2}$ performing Eq. 10. Although the reaction is thermodynamically feasible, the tolerance of the metal oxides to $\mathrm{CO}_{2} / \mathrm{CO}$ mixture should be considered. There could be a small fraction of $\mathrm{CO}$ changing direction in Eq. 10, and that would affect the reactor design and the purity of $\mathrm{CO}$ (mixture $\mathrm{CO}_{2} / \mathrm{CO}$ rich in $\mathrm{CO}$ ) obtained.

Manganese ( $\mathrm{Mn})$ cobalt $(\mathrm{Co})$, and iron $(\mathrm{Fe})$ are very similar elements, since they are very close on the periodic table and have very similar electron configuration [60,78]. Except for the different disproportionation temperature between each redox pairs, that is given by the better ability of Fe to stabilize the iron oxides. Consequently, the expected behaviour for the two redox pairs should be similar to $\mathrm{FeO} / \mathrm{Fe}_{3} \mathrm{O}_{4}$, with good kinetics and cyclability of the redox pair. On the other hand, use of doping agents, such as iron or nickel, can vary the disproportionation temperature $[40,41,74,75,79,80]$.

Studies indicate that Co can be oxidized/reduced from 30 cycles [[56]] and up to 100 cycles without reactivity loss [81]. This ensures the ability of cobalt to be reduced by thermal disproportionation, along with presumption of good oxidation with $\mathrm{CO}_{2}$, cobalt becomes a good candidate. Similarly to cobalt, other studies have shown the same behaviour with manganese [40,41]. Although manganese cyclability is not as good as that of cobalt, some studies [67] suggest that it is possible to improve its cyclability.

As the oxidation temperature of the metal oxide is lower than that of the disproportionation, this means that it can work below $1000^{\circ} \mathrm{C}$, complying with the first premise of the concept. Furthermore, the re-oxidation mechanism usually is controlled by oxygen diffusion inside the particle $[67,81]$. Although there is a maximum temperature which cannot be overcome, this will not have an important role in the kinetics. To improve kinetics it is essential to control the morphology and particle size of the metal oxide, and also to have a controlled atmosphere. To ensure morphology, minimizing sintering and maintaining surface/volume ratio, it may be advisable to decrease the disproportionation temperature.

Finally, considering the economic aspects, manganese is considered the best alternative for the regenerative cycle. Particularly, manganese has a cost approximately ten times lower than cobalt. 
Following the presented case study (2.2.2) and according to the patent submitted [17] the results of mass and energy balances and the plant diagram of this concept are presented in this section. To know how much potential and the viability of this concept, mass and heat balances for whole cycle of $\mathrm{BaSO}_{4} / \mathrm{BaS}$ coupled to $\mathrm{Mn}_{3} \mathrm{O}_{4} / \mathrm{Mn}_{2} \mathrm{O}_{3}$ cycle are provided. First of all, $\mathrm{BaSO}_{4} / \mathrm{BaS}$ balances are shown taking into account Eq. 4 and 5 (see Table 2, note that a basis of $100 \mathrm{~kg}$ of $\mathrm{BaSO}_{4}$ in solid state is taken for the balances). Then, operating modes during day and night for $\mathrm{BaSO}_{4} / \mathrm{BaS}$ cycle are detailed and afterwards the balances of the regenerative cycle (see Table 3 ) and the diagram of the whole concept are provided.

Table 2. Mass balance of $\mathrm{BaSO}_{4} / \mathrm{BaS}$ cycle

\begin{tabular}{|c|c|c|c|c|c|c|c|}
\hline Reaction & $1 \mathrm{BaSO}_{4}(\mathrm{~s})$ & + & $4 \mathrm{CO}(\mathrm{g})$ & $\rightarrow$ & $1 \mathrm{BaS}(\mathrm{s})$ & + & $4 \mathrm{CO}_{2}(\mathrm{~g})$ \\
\hline Mass $(\mathrm{kg})$ & 100.00 & & 48.00 & & 72.57 & & 75.43 \\
\hline $\begin{array}{c}\text { Molar mass } \\
(\mathrm{kg} / \mathrm{kmol})\end{array}$ & 233.34 & & 28.00 & & 169.34 & & 44.00 \\
\hline $\begin{array}{c}\text { Moles } \\
(\mathrm{kmol})\end{array}$ & 0.43 & & 1.71 & & 0.43 & & 1.71 \\
\hline Reaction & $1 \mathrm{BaS}(\mathrm{s})$ & + & $2 \mathrm{O}_{2}(\mathrm{~g})$ & $\rightarrow$ & $1 \mathrm{BaSO}_{4}(\mathrm{~s})$ & & \\
\hline Mass (kg) & 72.57 & & 27.43 & & 100.00 & & \\
\hline $\begin{array}{c}\text { Molar mass } \\
(\mathrm{kg} / \mathrm{kmol})\end{array}$ & 169.34 & & 32.00 & & 233.34 & & \\
\hline $\begin{array}{c}\text { Moles } \\
(\mathrm{kmol})\end{array}$ & 0.43 & & 0.86 & & 0.43 & & \\
\hline
\end{tabular}

380 The total energy released from both reactions for full conversion $(X=1)$ conditions is: -6680 $381 \mathrm{~kJ} / \mathrm{kg}$ of BaS (Eq. 4 and 5). However, this level of conversion is rarely reached by a chemical 382 reaction and therefore $60 \%$ is commonly used as level of conversion (conservative value). Then, 383 the total energy available for heating up the power block fluid would be $-4008 \mathrm{~kJ} / \mathrm{kg}$ of BaS. 


\section{a) Day / charging mode}

387

389

390

391

392

393

394

395

396

396

398

399

300

301

401

402

Day operation cycle works as follows (see also Figure 6):

- The reduction of $\mathrm{BaSO}_{4}$ to $\mathrm{BaS}$ takes place at $850^{\circ} \mathrm{C}$ thus it is needed the $\mathrm{BaSO}_{4}$ receiver to rise the temperature of the $\mathrm{BaSO} 4$ up to $850^{\circ} \mathrm{C}$;

- The $\mathrm{BaSO}_{4}$ enters into the reduction reactor at $850^{\circ} \mathrm{C}$ and it is reduced to $\mathrm{BaS}$ in contact with $\mathrm{CO}$ coming from the regenerative cycle;

- The reduction reaction gives $933 \mathrm{KJ} / \mathrm{kg}$ of $\mathrm{BaS}$. This heat is used to heat up the cold $\mathrm{sCO}_{2}$ in the reduction reactor - generator from $600^{\circ} \mathrm{C}$ to $802.3^{\circ} \mathrm{C}$

- The BaS stream coming out of the reduction reactor goes to the hot storage tank and in parallel to the oxidation reactor:

o $\mathrm{BaS}$ is stored in a silo to be oxidized in discharge mode;

o $\mathrm{BaS}$ is oxidized in the oxidation reactor with Air giving $5747 \mathrm{KJ} / \mathrm{kg} \mathrm{BaS}$. This heat is used to rise the temperature of the $\mathrm{sCO}_{2}$ stream up to $1150^{\circ} \mathrm{C}$

- The $\mathrm{BaSO}_{4}$ coming out of the oxidation reactor is sent to the $\mathrm{BaSO}_{4}$ receiver to be heated up again to $850^{\circ} \mathrm{C}$ to restart the cycle.

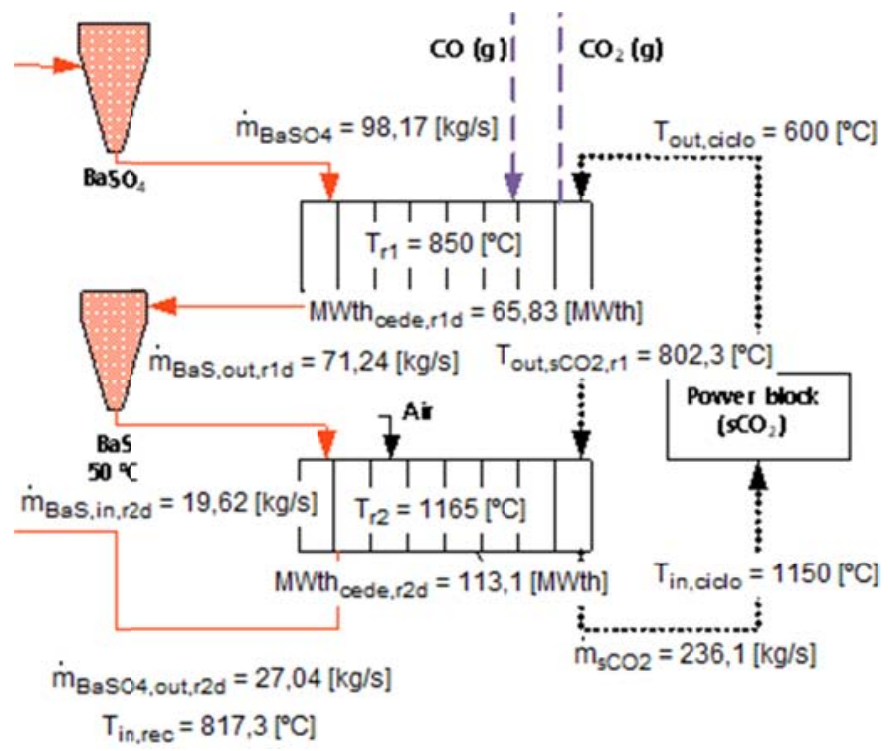

Figure 6. Operation mode during day (conversion reaction 99\%) 
406

409

410

411

410

411

413

414

416

417

418

417

Night cycle mode works as follows (see Figure 7):

- The BaS stored in the hot tank enters to the oxidation reactor and it is oxidized with Air giving $5747 \mathrm{KJ} / \mathrm{kg}$ of $\mathrm{BaS}$. This heat is used to bring the cold $\mathrm{sCO}_{2}$ stream from $600^{\circ} \mathrm{C}$ to $1150^{\circ} \mathrm{C}$;

- The $\mathrm{BaSO}_{4}$ outlet is stored in the cold tank at about $817^{\circ} \mathrm{C}$.

- The day after this $\mathrm{BaSO}_{4}$ would be again reduced and stored as $\mathrm{BaS}$ in the hot tank.

By this process the discharge could be performed only with an air inlet in the oxidation reactor avoiding the need of storing $\mathrm{CO} / \mathrm{CO}_{2}$.

If it was desired to be able to use both reactors in discharge mode a big storage system of $\mathrm{CO} / \mathrm{CO}_{2}$ or at least of the reactants of the regenerative cycle should be implemented avoiding the needs of storing solid particles of $\mathrm{BaS}$ and $\mathrm{BaSO}_{4}$.

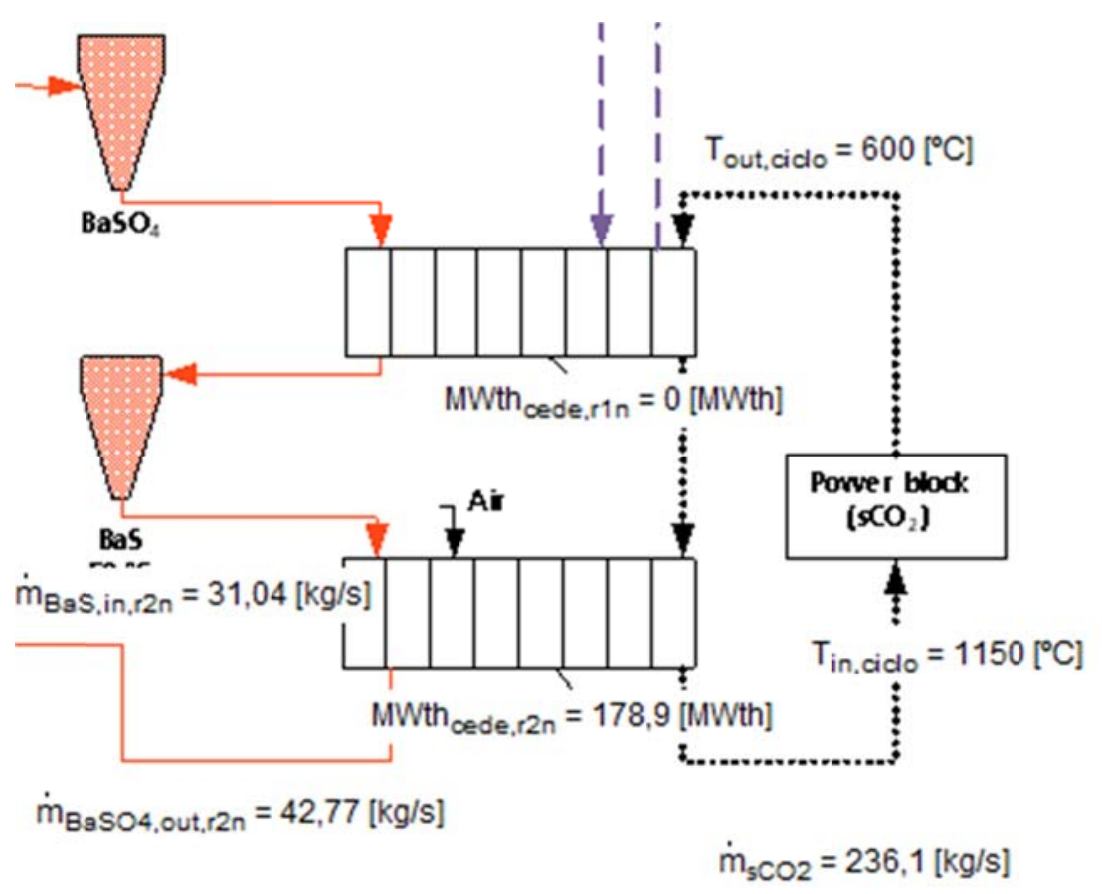

Figure 7. Operation mode at night (conversion reaction 99\%) 
421 The mass balance of the regenerative cycle following Eq. 6 and 7 is shown in Table 3, whereas

422 in Figure 8 the diagram of the whole concept implementation is drawn.

423 Table 3. Mass balance of $\mathrm{Mn}_{2} \mathrm{O}_{3} / \mathrm{Mn}_{3} \mathrm{O}_{4}$

\begin{tabular}{|c|c|c|c|c|c|c|c|}
\hline Reaction & $2 \mathrm{Mn}_{3} \mathrm{O}_{4}(\mathrm{~s})$ & + & $1 \mathrm{CO}_{2}(\mathrm{~g})$ & $\rightarrow$ & $3 \mathrm{Mn}_{2} \mathrm{O}_{3}(\mathrm{~s})$ & + & $1 \mathrm{CO}(\mathrm{g})$ \\
\hline Mass $(\mathrm{kg})$ & 784.50 & & 75.43 & & 811.93 & & 48.00 \\
\hline $\begin{array}{c}\text { Molar mass } \\
(\mathrm{kg} / \mathrm{kmol})\end{array}$ & 228.82 & & 44.00 & & 157.88 & & 28.00 \\
\hline $\begin{array}{c}\text { Moles } \\
(\mathrm{kmol})\end{array}$ & 3.43 & & 1.71 & & 5.14 & & 1.71 \\
\hline Reaction & $3 \mathrm{Mn}_{2} \mathrm{O}_{3}(\mathrm{~s})$ & $\rightarrow$ & $2 \mathrm{Mn}_{3} \mathrm{O}_{4}(\mathrm{~s})$ & + & $0.5 \mathrm{O}_{2}(\mathrm{~g})$ & & \\
\hline \begin{tabular}{c} 
Mass $(\mathrm{kg})$ \\
\hline $\begin{array}{c}\text { Molar mass } \\
(\mathrm{kg} / \mathrm{kmol})\end{array}$
\end{tabular} & 811.93 & & 784.50 & & 27.4 & & \\
\hline $\begin{array}{c}\text { Moles } \\
(\mathrm{kmol})\end{array}$ & 5.14 & & 3.43 & & 0.86 & & \\
\hline
\end{tabular}

425 The regenerative cycle, used for regenerating the $\mathrm{CO}$ for reducing $\mathrm{BaSO}_{4}$, is composed for two

426 endothermic reactions which need absorbing $2222 \mathrm{~kJ} / \mathrm{kg}$ of $\mathrm{Mn}_{2} \mathrm{O}_{3}$ for a full conversion reaction

427 (see Eq. 6 and 7). For these reactions, it has also considered a chemical conversion of $60 \%$ and 428 as consequence the total energy absorbed per $\mathrm{kg}$ of $\mathrm{Mn}_{2} \mathrm{O}_{3}$ is higher than for a full chemical 429 conversion. So, this energy increases until $3703 \mathrm{~kJ} / \mathrm{kg}$ of $\mathrm{Mn}_{2} \mathrm{O}_{3}$ for $60 \%$ of conversion.

430 The net energy value, released on $\mathrm{BaSO}_{4} / \mathrm{BaS}$ cycle and absorbed on $\mathrm{Mn}_{2} \mathrm{O}_{3} / \mathrm{Mn}_{3} \mathrm{O}_{4}$ cycle, 431 should be interpreted as $\mathrm{kJ}$ per $\mathrm{kg}$ of BaS. According to the mass balance (see Table 2 and 3 ), 432 for producing $72.57 \mathrm{~kg}$ of $\mathrm{BaS}$, the system needs $811.93 \mathrm{~kg}$ of $\mathrm{Mn}_{2} \mathrm{O}_{3}$, and thus the net energy 433 balance is $37165 \mathrm{~kJ}$ per $\mathrm{kg}$ of $\mathrm{BaS}$ for a $60 \%$ of chemical conversion. 


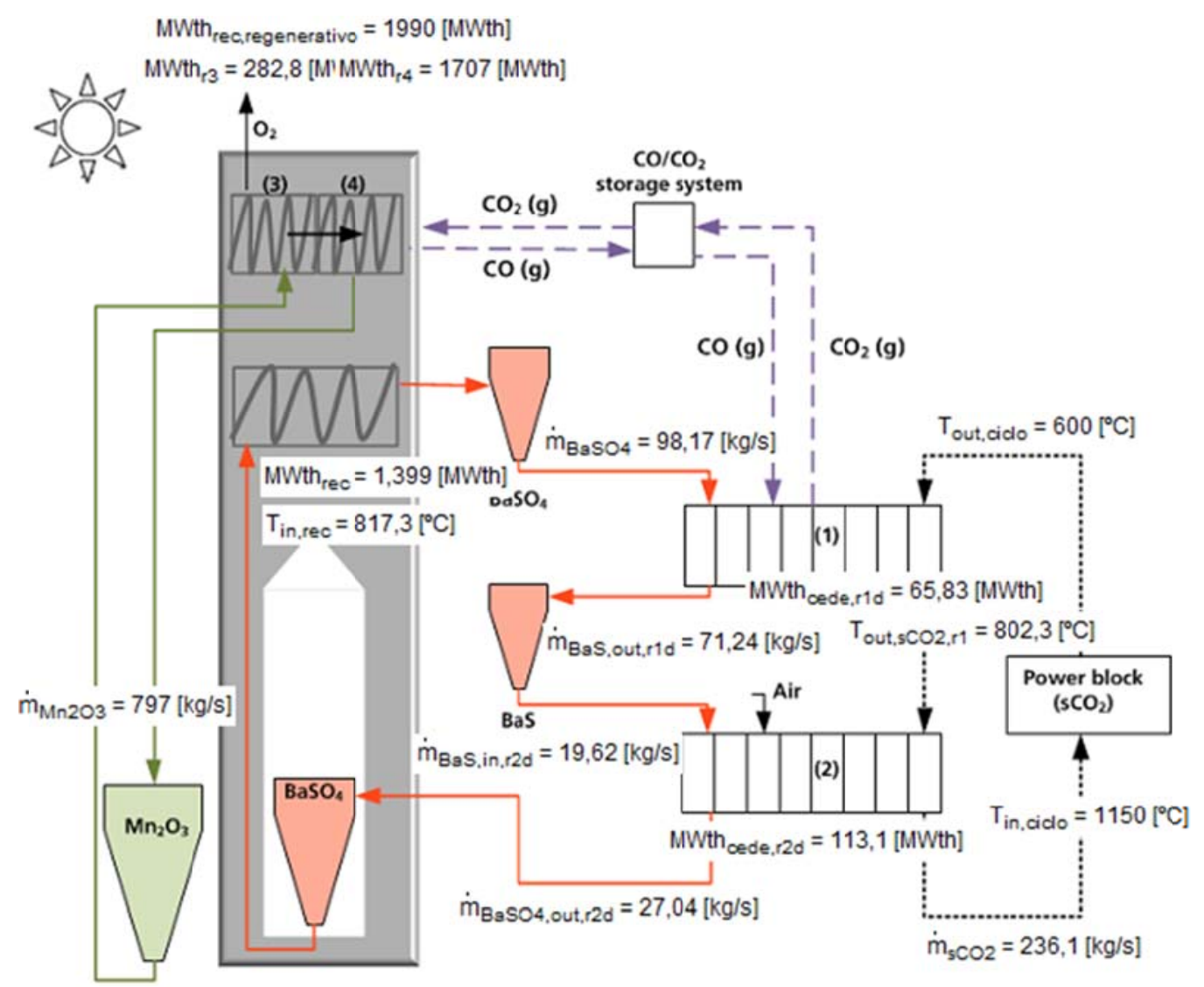

Figure 8. Plant diagram of the two coupled cycles of consecutive TCM reactions.

\section{Conclusions}

Concentrated solar power plants are potential technologies to increase the share of renewables and to reduce $\mathrm{CO}_{2}$ emissions and therefore contribute positively to Earth environment. Although there are some hybrids CSP, usually their primary energy is solar energy, to finally produce electricity. These technologies operate when the renewable energy is available and consequently to operate in continuous thermal energy storage (TES) should be considered. The R\&D of TCM as TES materials implemented in CSP, specifically for solar central receiver reactors, is now focused on looking for efficient reversible chemical reactions, and heat exchangers/reactors design. Regarding both, to increase the overall reactor efficiency, a new concept based on consecutive reactions TCM is presented.

454 Consecutive TCM reactions concepts have been detailed; first the one cycle concept which is based on two reactions, where the main product from the first reaction, in solid state, reacts with a gas $\left(\mathrm{CO}_{2}\right)$ to give again the reactive, solid, of the first reaction. Then the process can restart again, being $\mathrm{CO}_{2}$ the only external input. Whereas the second concept, based on two coupled 
cycles, is born with the idea of coupling another cycle of consecutive reaction to need o extra input of reactants.

456

457 Therefore, the proposed system store chemical compounds capable to release thermal energy.

458 By changing from reversible endothermic/exothermic reactions towards consecutive reactions a 459 higher chemical reaction conversion can be achieved and this would also contribute in a better material stability, leading to a longer material life time and thus longer operational plant periods.

\section{Acknowledgements}

464

The authors would like to thank the Catalan Government for the quality accreditation given to 466 the research group GREA (2014 SGR 123) and DIOPMA (2014 SGR 1543). The research leading to these results has received funding from the European Union's Seventh Framework Programme (FP7/2007-2013) under grant agreement $\mathrm{n}^{\circ}$ PIRSES-GA-2013-610692 (INNOSTORAGE) and from the European Union's Horizon 2020 research and innovation programme under grant agreement No 657466 (INPATH-TES). Dr. Camila Barreneche would like to thank Ministerio de Economia y Competitividad de España for Grant Juan de la Cierva, FJCI-2014-22886.

\section{References}

1. https://ec.europa.eu/programmes/horizon2020/en/h2020-section/secure-clean-and-efficientenergy (last accessed 19/01/16).

2. M. Liu, N.H.S. Tay, S. Bell, M. Belusko, R. Jacob, G. Will, W. Saman, and F. Bruno,"Review on concentrating solar power plants and new developments in high temperature thermal energy storage technologies", Renew. Sust. Energ. Rev., vol. 53, pp. 1411-1432, 2016.

3. H. I. Zhang, J. Baeyens, J. Degreve, G. Caceres. Concentrated solar power plants: Review and design methodology. Renew. Sust. Energ. Rev. vol. 22, pp. 466-481, 2013.

4. X. Py, Y. Azoumah, R Olives. Concentrated solar power: Curent technologies, major innovative issues and applicability to West African countries. Renew. Sust. Energ. Rev. vol. 18, pp. 306-315, 2013.

5. IEA-ETSAP and IRENA. Thermal energy storage. Technology brief E17. January 2013.

6. C. Prieto, P. Cooper, A. I. Fernández, L. F. Cabeza. Review of technology: thermochemical energy storage for concentrated solar power plants. Renew. Sust. Energ. Rev. vol. 60, pp. 909-929, 2016. 
7. A. Steinfeld, M. Brack, A. Meier, A. Weidenkaff, and D. Wuillemin, "A solar chemical reactor for co-production of zinc and synthesis gas," Energy, vol. 23, no. 10, pp. 803-814, Oct. 1998.

8. A. Zgraggen, P. Haueter, D. Trommer, M. Romero, J. de Jesus, and A. Steinfeld, "Hydrogen production by steam-gasification of petroleum coke using concentrated solar power-II Reactor design, testing, and modeling,” Int. J. Hydrogen Energy, vol. 31, no. 6, pp. 797-811, May 2006.

9. A. Zgraggen and A. Steinfeld, "Hydrogen production by steam-gasification of carbonaceous materials using concentrated solar energy - V. Reactor modeling, optimization, and scale-up," Int. J. Hydrogen Energy, vol. 33, no. 20, pp. 5484-5492, Oct. 2008.

10. A. Zgraggen, "Hydrogen production by steam-gasification of carbonaceous materials using concentrated solar energy-IV. Reactor experimentation with vacuum residue," Int. J. Hydrogen Energy, vol. 33, no. 2, pp. 679-684, Jan. 2008.

11. A. Kogan, "Production of hydrogen and carbon by solar thermal methane splitting. II. Room temperature simulation tests of seeded solar reactor," Int. J. Hydrogen Energy, vol. 29, no. 12, pp. 1227-1236, Sep. 2004.

12. M. Kogan, "Production of hydrogen and carbon by solar thermal methane splitting. I. The unseeded reactor," Int. J. Hydrogen Energy, vol. 28, no. 11, pp. 1187-1198, Nov. 2003.

13. D. Hirsch, "Solar hydrogen production by thermal decomposition of natural gas using a vortex-flow reactor,” Int. J. Hydrogen Energy, vol. 29, no. 1, pp. 47-55, Jan. 2004.

14. K. J. Albrecht, G.S. Jackson, R. J. Braun, "Thermodynamically consistent modeling of redox-stable perovskite oxide for thermochemical energy conversion and storage,". Applied Energy, vol. 165, pp. 285-296, 2016.

15. R. Chacartegui, A. Alovisio, C. ortiz, J.M. valverde, V. Verda, J.A. Becerra, "Thermochemical energy storage of concetrated solar power by integration of the calcium looping process and a CO2 power cycle," Applied Energy, vol. 173, pp. 589-605, 2016.

16. K.E. N'Tsoukpoe, T. Osterland, O. Opel, W.K.L Ruck, “ Cascade thermochemical storage with internal condensation heat recovery for better energy and exergy efficiencies," Applied Energy, vol. 181, pp. 562-574, 2016.

17. M. Deutsch, D. Müller, C. Aumeyr, C. Jordan, C. Gierl-Mayer, P. Weinberger, F. Winter, A. Werner," Systematic search algorithm for potential thermochemical energy storage systems," Applied Energy, vol. 183, pp. 113-120, 2016.

18. A. Kogan and M. Kogan, "The Tornado Flow Configuration-An Effective Method for Screening of a Solar Reactor Window,” J. Sol. Energy Eng., vol. 124, no. 3, pp. 206, 2002. 
19. G. Flamant, D. Hernandez, C. Bonet, and J.-P. Traverse, "Experimental aspects of the thermochemical conversion of solar energy; Decarbonation of $\mathrm{CaCO}_{3}$," Sol. Energy, vol. 24, no. 4, pp. 385-395, Jan. 1980.

20. L.F. Cabeza, A. I. Fernandez, X. Fontanet, J. Chimenos, C. Prieto, M. Alguacil. Planta de potencia con almacenamiento termoquímico basado en un ciclo de reacciones y su método de funcionamiento: ES2574352 (A1) - 2016-06-16.

21. L.F. Cabeza, A. I. Fernandez, X. Fontanet, J. Chimenos, C. Prieto, M. Alguacil. Planta de potencia con almacenamiento termoquímico y su método de funcionamiento: ES2574327 (A1) - 2016-06-16.

22. M. E. Gálvez, P. G. Loutzenhiser, I. Hischier, and A. Steinfeld, " $\mathrm{CO}_{2}$ Splitting via TwoStep Solar Thermochemical Cycles with $\mathrm{Zn} / \mathrm{ZnO}$ and $\mathrm{FeO} / \mathrm{Fe}_{3} \mathrm{O}_{4}$ Redox Reactions: Thermodynamic Analysis," Energy \& Fuels, vol. 22, no. 5, pp. 3544-3550, Sep. 2008.

23. P. G. Loutzenhiser, M. E. Gálvez, I. Hischier, A. Stamatiou, A. Frei, and A. Steinfeld, " $\mathrm{CO}_{2}$ Splitting via Two-Step Solar Thermochemical Cycles with $\mathrm{Zn} / \mathrm{ZnO}$ and $\mathrm{FeO} / \mathrm{Fe}_{3} \mathrm{O}_{4}$ Redox Reactions II: Kinetic Analysis,” Energy \& Fuels, vol. 23, no. 5, pp. 2832-2839, May 2009.

24. R. Müller, P. Haeberling, and R. D. Palumbo, "Further advances toward the development of a direct heating solar thermal chemical reactor for the thermal dissociation of $\mathrm{ZnO}(\mathrm{s})$," Sol. Energy, vol. 80, no. 5, pp. 500-511, May 2006.

25. P. Haueter, S. Moeller, R. Palumbo, and A. Steinfeld, "The production of zinc by thermal dissociation of zinc oxide - Solar chemical reactor design," Sol. Energy, vol. 67, no. 1-3, pp. 161-167, 1999.

26. CRC handbook of chemistry and physics. Boca Raton, FL. [etc.] : CRC Press, 1977.

27. S. Abanades and H. I. Villafan-Vidales, " $\mathrm{CO}_{2}$ and $\mathrm{H}_{2} \mathrm{O}$ conversion to solar fuels via twostep solar thermochemical looping using iron oxide redox pair," Chem. Eng. J., vol. 175, no. 1, pp. 368-375, Nov. 2011.

28. S. Abanades and I. Villafan-Vidales, " $\mathrm{CO}_{2}$ valorisation based on $\mathrm{Fe} 3 \mathrm{O} 4 / \mathrm{FeO}$ thermochemical redox reactions using concentrated solar energy,” Int. J. Energy Res., vol. 37, no. 6, pp. 598-608, May 2013.

29. L. O. Schunk, W. Lipiński, and A. Steinfeld, "Heat transfer model of a solar receiverreactor for the thermal dissociation of $\mathrm{ZnO}$ - Experimental validation at $10 \mathrm{~kW}$ and scaleup to 1MW,” Chem. Eng. J., vol. 150, no. 2-3, pp. 502-508, Aug. 2009.

30. L. O. Schunk, P. Haeberling, S. Wepf, D. Wuillemin, A. Meier, and A. Steinfeld, "A Receiver-Reactor for the Solar Thermal Dissociation of Zinc Oxide," J. Sol. Energy Eng., vol. 130, no. 2, p. 021009, 2008.

31. P. Pascal, "Tome IV: Groupe II," in Nouveau traité de chimie minérale, Masson, S.A, 1968. 
32. O. Kubaschewski and C. B. Alcock, Metallurgical thermochemistry. : Pergamon Press, 1983.

33. R. C. Ropp, Encyclopedia of the alkaline earth compounds. Amsterdam : Elsevier, 2013.

34. F. Yang, C. Wu, Y. Cui, G. Lu, "Apparent activation energy for spontaneous combustion of sulfide concentrates in storage yard," Trans. Nonferrous Met. Soc. China, vol. 21, no. 2, pp. 395-401, Feb. 2011.

35. E. Jerndal, T. Mattisson, and A. Lyngfelt, "Thermal Analysis of Chemical-Looping Combustion,” Chem. Eng. Res. Des., vol. 84, no. 9, pp. 795-806, Sep. 2006.

36. A. Gil, M. Medrano, I. Martorell, A. Lázaro, P. Dolado, B. Zalba, and L. F. Cabeza, "State of the art on high temperature thermal energy storage for power generation. Part 1Concepts, materials and modellization,” Renew. Sustain. Energy Rev., vol. 14, no. 1, pp. 31-55, Jan. 2010.

37. P. Pardo, A. Deydier, Z. Anxionnaz-Minvielle, S. Rougé, M. Cabassud, and P. Cognet, “A review on high temperature thermochemical heat energy storage," Renew. Sustain. Energy Rev., vol. 32, pp. 591-610, Apr. 2014.

38. M. Felderhoff, R. Urbanczyk, and S. Peil, "Thermochemical Heat Storage for High Temperature Applications - A Review," Green, vol. 3, no. 2, pp. 113-123, Jan. 2013.

39. E. Alonso, C. Pérez-Rábago, J. Licurgo, E. Fuentealba, and C. A. Estrada, "First experimental studies of solar redox reactions of copper oxides for thermochemical energy storage,” Sol. Energy, vol. 115, pp. 297-305, May 2015.

40. J. M. C. Alfonso J. Carrillo, David P. Serrano, Patricia Pizarro, "Improving the performance of thermochemical heat storage at high temperatures based on redox metal oxides," in Eurotherm Seminar \#99, 2014.

41. A. J. Carrillo, J. Moya, A. Bayón, P. Jana, V. A. de la Peña O’Shea, M. Romero, J. Gonzalez-Aguilar, D. P. Serrano, P. Pizarro, and J. M. Coronado, "Thermochemical energy storage at high temperature via redox cycles of $\mathrm{Mn}$ and Co oxides: Pure oxides versus mixed ones," Sol. Energy Mater. Sol. Cells, vol. 123, pp. 47-57, Apr. 2014.

42. A. Steinfeld and R. Palumbo, Solar Thermochemical Process Technology. Elsevier, 2003.

43. C. Graves, S. D. Ebbesen, M. Mogensen, and K. S. Lackner, "Sustainable hydrocarbon fuels by recycling $\mathrm{CO}_{2}$ and $\mathrm{H}_{2} \mathrm{O}$ with renewable or nuclear energy," Renew. Sustain. Energy Rev., vol. 15, no. 1, pp. 1-23, Jan. 2011.

44. S. Abanades, P. Charvin, G. Flamant, and P. Neveu, "Screening of water-splitting thermochemical cycles potentially attractive for hydrogen production by concentrated solar energy," Energy, vol. 31, no. 14, pp. 2805-2822, Nov. 2006.

45. S. Abanades and I. Villafan-Vidales, "CO 2 valorisation based on $\mathrm{Fe} 3 \mathrm{O} 4 / \mathrm{FeO}$ thermochemical redox reactions using concentrated solar energy," Int. J. Energy Res., vol. 37, no. 6, pp. 598-608, May 2013. 
46. G. Levêque, S. Abanades, J.-C. Jumas, and J. Olivier-Fourcade, "Characterization of TwoStep Tin-Based Redox System for Thermochemical Fuel Production from Solar-Driven CO 2 and H 2 O Splitting Cycle,” Ind. Eng. Chem. Res., vol. 53, no. 14, pp. 5668-5677, Apr. 2014.

47. J. R. Scheffe and A. Steinfeld, "Oxygen exchange materials for solar thermochemical splitting of $\mathrm{H} 2 \mathrm{O}$ and CO2: a review," Mater. Today, vol. 17, no. 7, pp. 341-348, Sep. 2014.

48. M. Romero and A. Steinfeld, "Concentrating solar thermal power and thermochemical fuels," Energy Environ. Sci., vol. 5, no. 11, p. 9234, 2012.

49. P. S. Hlabela, H. W. J. P. Neomagus, F. B. Waanders, and O. S. L. Bruinsma, "Thermal reduction of barium sulphate with carbon monoxide-A thermogravimetric study," Thermochim. Acta, vol. 498, no. 1-2, pp. 67-70, Jan. 2010.

50. Y. Pelovski and M. Taniguchi, "Barium sulphate reduction with carbon," J. Therm. Anal., vol. 33, no. 3, pp. 603-608, Sep. 1988.

51. L. A. Malysh, L. G. Gaisin, M. F. Volkova, A. G. Prokhorov, and K. V. Tkachev, "Reduction of recycled barium -ulfate," Russ. J. Appl. Chem., vol. 75, no. 1, pp. 14-17, 2002.

52. S. B. Jagtap, A. R. Pande, and A. N. Gokarn, "Effect of catalysts on the kinetics of the reduction of barite by carbon," Ind. Eng. Chem. Res., vol. 29, no. 5, pp. 795-799, 1990.

53. A. Salem and Y. T. Osgouei, "The effect of particle size distribution on barite reduction," Mater. Res. Bull., vol. 44, no. 7, pp. 1489-1493, Jul. 2009.

54. S. Jamshidi and A. Salem, "Role of extrusion process on kinetic of carbothermal reduction of barite," Thermochim. Acta, vol. 503-504, no. 1, pp. 108-114, May 2010.

55. A. Salem and S. Jamshidi, "Effect of paste humidity on kinetics of carbothermal reduction of extruded barite and coke mixture," Solid State Sci., vol. 14, no. 8, pp. 1012-1017, Aug. 2012.

56. M. S. Bafghi, A. Yarahmadi, A. Ahmadi, and H. Mehrjoo, "Effect of the type of carbon material on the reduction kinetics of barium sulfate,” Iran. J. Mater. Sci. Eng., vol. 8, no. 3, pp. 1-7, 2011.

57. W. Zhang, Y. Zhou, J. Zhu, and Y. Pan, "New Clean Process for Barium Sulfide Preparation by Barite Reduction with Elemental Sulfur,” Ind. Eng. Chem. Res., vol. 53, no. 14, pp. 5646-5651, Apr. 2014.

58. H. Y. Sohn, M. Savic, R. Padilla, and G. Han, "A novel reaction system involving BaS and for converting to elemental sulfur without generating pollutants: Part I. Feasibility and kinetics of reduction with BaS," Chem. Eng. Sci., vol. 61, no. 15, pp. 5082-5087, Aug. 2006. 
59. O. Kubaschewski, P. J. Spencer, and C. B. Alcock, Materials thermochemistry. New York : Pergamon Press, 1993.

60. G. Rayner-Canham, Descriptive inorganic chemistry. New York : Freeman, 1996.

61. K. H. Büchel, H.-H. Moretto, and P. Woditsch, Industrial inorganic chemistry. Weinheim: Wiley-VCH, 2000.

62. F. Tegeder and L. Mayer, Métodos de la industria química: en diagramas de flujo coloreados. Barcelona [etc.] : Reverté, 1978.

63. J. H. Cameron and T. M. Grace, "Kinetic study of sulfate reduction with carbon," Ind. Eng. Chem. Fundam., vol. 22, no. 4, pp. 486-494, 1983.

64. J. A. Kaeser, J. Tanaka, J. C. Douglass, and R. D. Hill, "Hydrosulfides of group I and group II metals," Inorganic Chemistry, vol. 12, no. 12. pp. 3019-3020, 1973.

65. Ch. Chorower, "Sulfuro de bario. Productos de su descomposición, sus métodos analíticos y su solubilidad," An. física y química, vol. 37, pp. 409-545, 1941.

66. C. B. Carter and M. G. Norton, Ceramic materials : science and engineering. New York: Springer, 2007.

67. A. J. Carrillo, D. P. Serrano, P. Pizarro, and J. M. Coronado, "Thermochemical heat storage based on the $\mathrm{Mn}_{2} \mathrm{O}_{3} / \mathrm{Mn}_{3} \mathrm{O}_{4}$ redox couple: influence of the initial particle size on the morphological evolution and cyclability," J. Mater. Chem. A, vol. 2, no. 45, pp. $19435-$ 19443, Oct. 2014.

68. J. R. Scheffe and A. Steinfeld, "Oxygen exchange materials for solar thermochemical splitting of $\mathrm{H}_{2} \mathrm{O}$ and $\mathrm{CO}_{2}$ : a review," Mater. Today, vol. 17, no. 7, pp. 341-348, Sep. 2014.

69. E. Yamasue, H. Yamaguchi, H. Nakaoku, H. Okumura, and K. N. Ishihara, "Carbon dioxide reduction into carbon by mechanically milled wustite,” J. Mater. Sci., vol. 42, no. 13, pp. 5196-5202, Feb. 2007.

70. W. C. Chueh, C. Falter, M. Abbott, D. Scipio, P. Furler, S. M. Haile, and A. Steinfeld, "High-flux solar-driven thermochemical dissociation of $\mathrm{CO}_{2}$ and $\mathrm{H}_{2} \mathrm{O}$ using nonstoichiometric ceria.," Science, vol. 330, no. 6012, pp. 1797-801, Dec. 2010.

71. G. Levêque and S. Abanades, "Thermodynamic and Kinetic Study of the Carbothermal Reduction of $\mathrm{SnO}_{2}$ for Solar Thermochemical Fuel Generation,” Energy \& Fuels, vol. 28, no. 2, pp. 1396-1405, Feb. 2014.

72. P. Pascal, "Tome XVII: Co Ni," in Nouveau traité de chimie minérale, Masson, S.A, 1963.

73. P. Pascal, "Tome XVI: Fluor, brome, iode, astate, manganèse, technétium, rhénium," in Nouveau traité de chimie minérale, Masson, S.A, 1960.

74. T. Block, N. Knoblauch, and M. Schmücker, "The cobalt-oxide/iron-oxide binary system for use as high temperature thermochemical energy storage material," Thermochim. Acta, vol. 577, pp. 25-32, Feb. 2014. 
75. J. V. Crum, B. J. Riley, and J. D. Vienna, "Binary Phase Diagram of the Manganese OxideIron Oxide System,” J. Am. Ceram. Soc., vol. 92, no. 10, pp. 2378-2384, Oct. 2009.

76. M. Neises, S. Tescari, L. de Oliveira, M. Roeb, C. Sattler, and B. Wong, "Solar-heated rotary kiln for thermochemical energy storage," Sol. Energy, vol. 86, no. 10, pp. 30403048, Oct. 2012.

77. A. Ballester, Metalurgia extractiva. Madrid : Síntesis, 2000.

78. P. W. Atkins and J. De Paula, Atkins' physical chemistry. Oxford [etc.]: Oxford University Press, 2006.

79. I.-H. Jung, S. A. Decterov, A. D. Pelton, H.-M. Kim, and Y.-B. Kang, "Thermodynamic evaluation and modeling of the Fe-Co-O system," Acta Mater., vol. 52, no. 2, pp. 507519, Jan. 2004.

80. C. Pagkoura, G. Karagiannakis, A. Zygogianni, S. Lorentzou, M. Kostoglou, A. G. Konstandopoulos, M. Rattenburry, and J. W. Woodhead, "Cobalt oxide based structured bodies as redox thermochemical heat storage medium for future CSP plants," Sol. Energy, vol. 108, pp. 146-163, Oct. 2014.

81. K. Hutchings, M. Wilson, P. Larsen, and R. Cutler, "Kinetic and thermodynamic considerations for oxygen absorption/desorption using cobalt oxide," Solid State Ionics, vol. 177, no. 1-2, pp. 45-51, Jan. 2006. 